\title{
Comparative Study of Conventional Drill Bits and a New Model for Low-rotation in the Surgical Bed Preparation in Bone Blocks for Installation of Dental Implants
}

\author{
Primo Herrera Subelza ${ }^{1, *}$, Gino Kopp ${ }^{2}$, Maurício Fernando Herrera Sivila ${ }^{3}$, Henry Kevin Herrera Sivila ${ }^{4}$, Carlos Eduardo Francischone ${ }^{1,5}$ \\ 'São Leopoldo Mandic School of Dentistry, Campinas, São Paulo, BRAZIL. \\ IInstituto Kopp Odontologia, Curitiba, Paraná, BRAZIL. \\ ${ }^{3}$ Centro Odontologico Herrera, Sucre, BOLIVIA. \\ ¿Universidad Mayor Realy Pontificia San Francisco Xavier de Chuquisaca, Sucre, BOLIVIA. \\ 5University of São Paulo, Bauru, São Paulo, BRAZIL.
}

\begin{abstract}
Background: Many works in Dentistry have aimed toward improving bone regeneration and oral rehabilitation through techniques, procedures and materials of Implantology. Objective of this study is to comparethe heating intensity of bovine blocks, simulating surgical beds using different drills. Materials and Methods: We evaluated 24 blocks divided into 4 groups with different KOPP brand drill models: G1-Conventional drills without ifrigation; G2-Experimental drills without irrigation; G3-Conventional drills with irrigation; G4-Experimental drills with irrigation. Perforations were performed with depths of 1.0 and $5.00 \mathrm{~mm}$, drill rotation speed of $150 \mathrm{rpm}$ and torque of $45 \mathrm{~N}$. Two K-type thermocouples were used to measure the temperature of the bone, with the first in the $1 \mathrm{~mm}$ deep perforation and the second in the $5 \mathrm{~mm}$ perforation. Results: In comparing the conventional and experimental drills treated with the same kind of protocol there was no statistical difference in the depth of $1 \mathrm{~mm}(p>0.05)$, however a statistical difference was observed at the depth of $5 \mathrm{~mm}(p<0.05)$. When comparing the temperature of each drill there was statistical difference
\end{abstract}

between the groups treated with no irrigation (G1 and G2) compared to the groups treated with the irrigation protocol (G3 and G4) and the last two had a significant reduction in the temperature of the two studied depths $(p<$ $0.001)$. Conclusion: The groups of the bovine blocks treated with irrigation showed lower temperature records when compared to the groups without irrigation protocol in both studied depths.

Key words: Bone, Dental implants, Irrigation, Osseointegration, Surgical cutters.

\section{Correspondence}

Dr Primo Herrera Subelza,

School of Dentistry, 13 José Rocha Junqueira, 13045-755- Pte. Preta, Campinas, São Paulo, BRAZIL.

Phone no: +551932113600

Email: primoimplanto@gmail.com

DOI: 10.5530/jyp.2019.11.88

\section{INTRODUCTION}

Edentulism is a condition that exists in all countries, however the technological advancement of Dentistry has enabled the development and emergence of many means of oral rehabilitation. ${ }^{1}$ With the clinical and scientific proof of osseointegration, dental implant treatment has been consolidated as a reality in the dental clinic. Thus, the search for osseointegration and preservation of peri-implant bone tissue has been intense in recent years. ${ }^{2,3}$

Many works in Dentistry in recent years have aimed toward improving bone regeneration and oral rehabilitation through techniques, procedures and materials placed on the market of Implantology. Industries are increasingly investing in innovation of products to ensure competitiveness and to remain on the market. A properly planned surgery with the proper choice of the implant type, surgical technique and appropriate biosecurity will likely achieve clinical success. ${ }^{4}$

Nowadays, various types and formats of implants are constantly released on the market. The development of new materials is due to the search for improving implants to prevent failures on osseointegration. There are several variables in implant failure prevention, such as surface modification, implant material, implant geometry, training and professional technique. All these factors may decisively influence osseointegration. ${ }^{5}$

When the surgical bed preparation for installing dental implants with conventional surgical cutters is completed, the aggression of osteogenic cells, blood cells and undifferentiated cells is inevitable due to friction by bone compression which ends up causing osteonecrosis and cell death of important elements that may jeopardize the osseointegration. ${ }^{6,7}$

According to Nero et al. ${ }^{8}$ the temperature threshold that the bone tissue can reach is between $44^{\circ} \mathrm{C}$ to $47^{\circ} \mathrm{C}$ for one min. Some of the factors which influence increasing this temperature is the rotational speed and the drill drawing. A protocol held at low speed decreases the stress caused to the bone and the bone resorption is smaller. Therefore, the objective of this study was to evaluate different irrigation techniques in controlling bone temperature during osteotomies, comparing a conventional system to an experimental one for the installation of dental implants (INPI, BR 20 2017010735 9). ${ }^{9}$

\section{MATERIALS AND METHODS}

\section{Group division}

A methodology similar to that of Nero et al. ${ }^{8}$ was followed in this study. The motor and contra-angles used for the perforations were both of the Driller brand, Brazilian industry. The surgical contra-angle was fixed to the equipment, always allowing the same angulation and the same reduction in all osteotomies.

This experimental model shows a lower area of contact and consequently lower friction during the making of the surgical alveolus. Also has better 
cutting power at the end due to front and side edging. The macro structure of the drill has a chamfer of 180 degrees and undulations in the longitudinal direction (Figure 1).

The surgical motor was coupled to the contra-angle guaranteeing the same rotational speed $(150 \mathrm{rpm})$ of the drills and the same torque. A total of 24 bovine blocks were donated, approximately $14 \mathrm{~cm}$ long 13 $\mathrm{mm}$ wide, $20 \mathrm{~mm}$ high and approximately $2 \mathrm{~mm}$ cortical bone (Figure 2). The blocks were previously prepared and divided into four groups. We evaluated 24 bovine blocks divided into 4 groups, 6 blocks per group for analysis in triplicate, with different KOPP brand drill models (Brazilian industry), evaluated under rotation of $150 \mathrm{rpm}$ : G1 - conventional drills without irrigation; G2 - experimental drills without irrigation; G3 conventional drills with irrigation; G4 - experimental drills with irrigation. The perforations were performed with depths of 1.0 and $5.0 \mathrm{~mm}$, rotational speed of the drill at $150 \mathrm{rpm}$ and torque of $45 \mathrm{~N}$.

Two K-type thermocouples attached to a portable digital thermometer (Tasi, model 8620) were used to measure the bone temperature and the thermometer was calibrated to measure the temperature at the depths of $1 \mathrm{~mm}$ and $5 \mathrm{~mm}$. The edges of the thermocouples were stabilized with photopolymerizable resin. A thermostatic box was used so that the experiments were carried out at a temperature of $37^{\circ} \mathrm{C}$ and the blocks were $3 / 4$ covered, thus simulating a moisture approximate to that of the oral cavity (Figure 3 ).

The data were tabulated in Microsoft Office Excel software and exported to SigmaPlot version 11.0 software. The analyses were performed adopting a confidence level of $95 \%(P<0.05)$. The data were expressed as means and standard error. The quantitative data were analyzed by the normality test and compared using the Student's $t$-test and Chi-squared test, as appropriate.

\section{RESULTS}

When evaluating the mean temperature values at $1 \mathrm{~mm}$ depth in the different protocols (with and without irrigation), the mean temperature value in $\mathrm{G} 1$ was $25.95 \pm 0.46^{\circ} \mathrm{C}$. Maintaining the same previous characteristics except only changing the experimental drills (G2), the mean value was $25.22 \pm 0.44^{\circ} \mathrm{C}$. Furthermore, the mean value in $\mathrm{G} 3$ was $21.01 \pm 0.52^{\circ} \mathrm{C}$ and in $\mathrm{G} 4$ the mean value was $19.79 \pm 0.48^{\circ} \mathrm{C}$. When evaluating the mean temperature values at $5 \mathrm{~mm}$ depth in the different protocols (without and with irrigation), the mean temperature value in $\mathrm{G} 1$ was $30.59 \pm 0.47^{\circ} \mathrm{C}$. Maintaining the same previous characteristics except only changing the experimental drills (G2), the mean value was $29.74 \pm 0.41^{\circ} \mathrm{C}$. In $\mathrm{G} 3$ the mean value was $27.27 \pm 0.39^{\circ} \mathrm{C}$ and in $\mathrm{G} 4$ the mean value was $24.91 \pm 0.42^{\circ} \mathrm{C}$. There was no statistical difference between the groups.

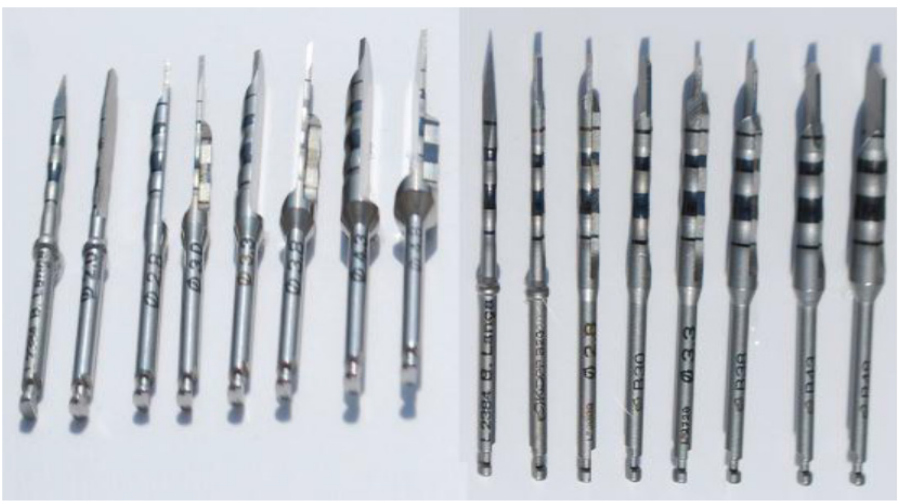

Figure 1: Conventional and experimental drill designs, respectively. Left: Conventional drills; Right: Experimental drills.

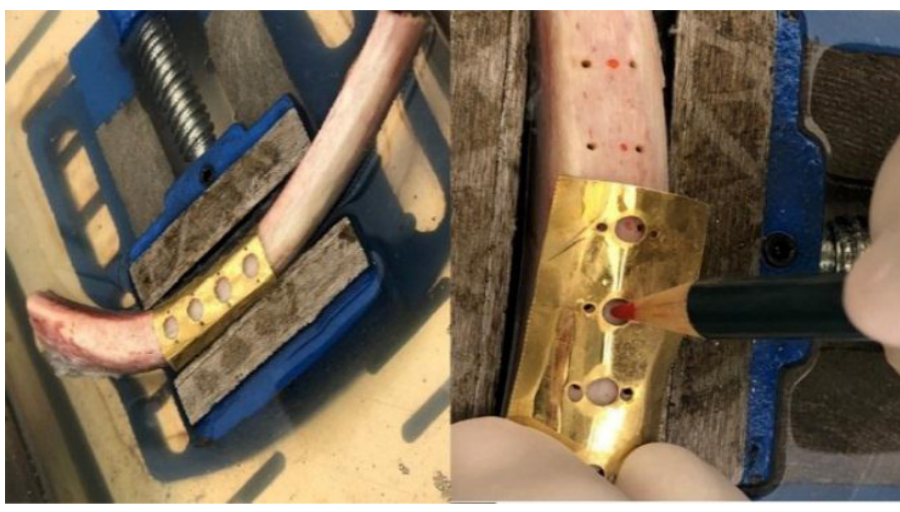

Figure 2: Adaptation of bovine bone and marking of points to be pierced. Preparation of the model to simulate the surgical bed.

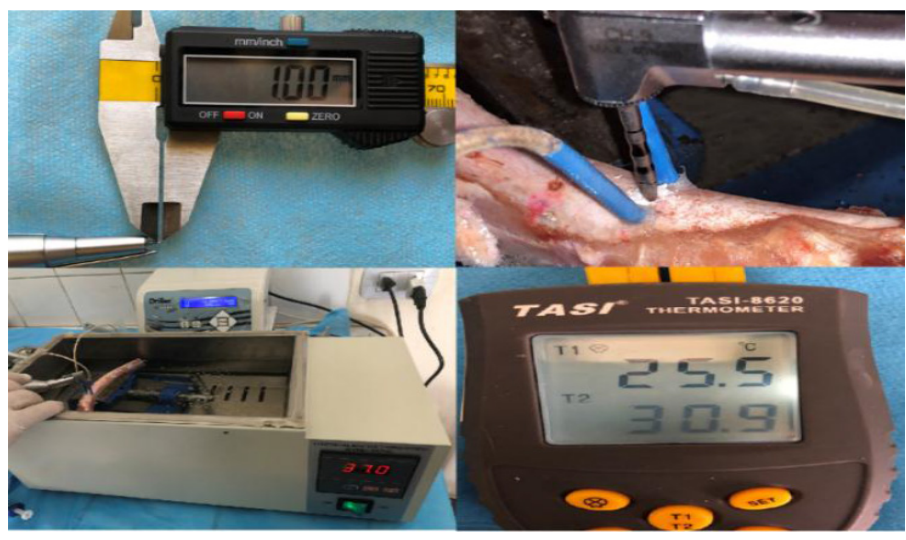

Figure 3: Calibration of the depths and adaptation of thermocouples; Sample immersed in thermostatic water box and temperature record (below).

Thermocouples and preparation of the bones.

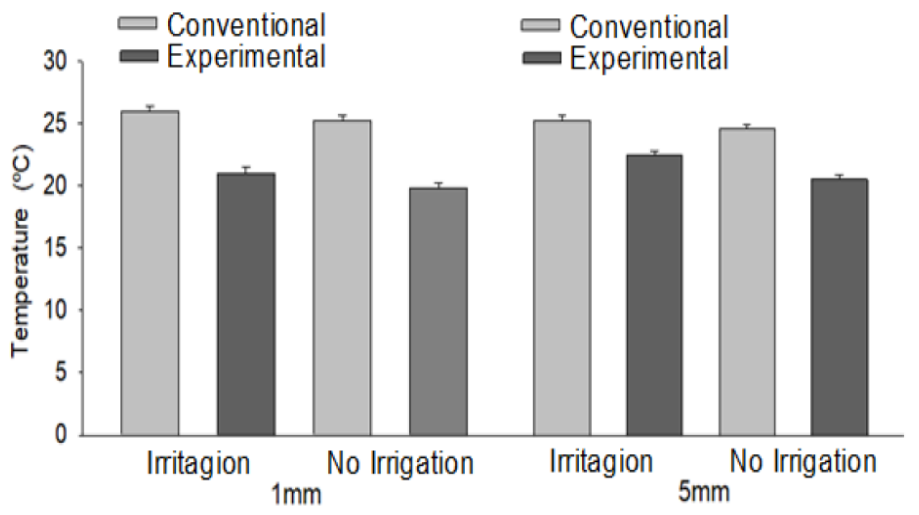

Figure 4: Average values of the block temperatures at depths of $1 \mathrm{~mm}$ and $5 \mathrm{~mm}$ at 150 RPM with and without irrigation with conventional drills and experimental KOPP brand drills.

Table 1 shows the intra and inter comparison of the block temperatures without irrigation with conventional drills. The minimum temperature at the depth of $1 \mathrm{~mm}$ occurred in the $3.0 \mathrm{~mm}$ drill $=24^{\circ} \mathrm{C}$ and the maximum in the $3.8 \mathrm{~mm}$ drill $=27.5^{\circ} \mathrm{C}$, while the minimum temperature at the depth of $5 \mathrm{~mm}$ was $28.7^{\circ} \mathrm{C}$ in the $2.0 \mathrm{~mm}$ drill and $32.1^{\circ} \mathrm{C}$ in the $4.8 \mathrm{~mm}$ drill. There was statistical difference between the temperatures in 
the intragroup comparison of each depth $(p<0.001)$, however there was no statistical difference in the Intergroup analysis $(p=0.22)$.

Table 2 shows the different values in the experimental protocol without irrigation. The minimum temperature at the depth of $1 \mathrm{~mm}$ occurred in the $3.0 \mathrm{~mm}$ drill $=23.3^{\circ} \mathrm{C}$ and the maximum at the spear $=27^{\circ} \mathrm{C}$ and the minimum temperature at the depth of $5 \mathrm{~mm}$ was $28.0^{\circ} \mathrm{C}$ in the $2.0 \mathrm{~mm}$ drill and $31.1^{\circ} \mathrm{C}$ in the $4.8 \mathrm{~mm}$ drill. There was a statistical difference between the temperatures in the intragroup comparison of each depth $(p<0.001)$, while there was no statistical difference in the Intergroup analysis $(P=0.25)$.

Table 3 describes the temperatures in the irrigation protocol with conventional drills. The minimum temperature at the depth of $1 \mathrm{~mm}$ occurred in the $2.0 \mathrm{~mm}$ drill $=18.5^{\circ} \mathrm{C}$ and the maximum in the $2.8-4.8 \mathrm{~mm}$ drill $=21.8^{\circ} \mathrm{C}$, while the minimum temperature at the depth of $5 \mathrm{~mm}$ was $26.2^{\circ} \mathrm{C}$ in the $2.0 \mathrm{~mm}$ drill and $28.9^{\circ} \mathrm{C}$ in the drill $2.8 \mathrm{~mm}$. (Table 3 ). The minimum temperature at the depth of $1 \mathrm{~mm}$ occurred in the $2.0 \mathrm{~mm}$ drill $=18.5^{\circ} \mathrm{C}$ and the maximum in the $2.8-4.8 \mathrm{~mm}$ drill $=21.8^{\circ} \mathrm{C}$, while the minimum temperature at the depth of $5 \mathrm{~mm}$ was $26.2^{\circ} \mathrm{C}$ in the $2.0 \mathrm{~mm}$ drill and $28.9^{\circ} \mathrm{C}$ in the $2.8 \mathrm{~mm}$ drill (Table 3). There was a statistical difference between the temperatures in the intragroup comparison of each depth $(p<0.001)$, but there was no statistical difference in the Intergroup analysis $(P=0.78)$.

Table 4 describes the values of the experimental protocol with irrigation. The minimum temperature at the depth of $1 \mathrm{~mm}$ occurred in the spear drill $=18^{\circ} \mathrm{C}$ and the maximum in the $4.3 \mathrm{~mm}$ drill $=22.1^{\circ} \mathrm{C}$, while the

Table 1: Description of the block temperatures at each depth at 150 RPM without irrigation with conventional KOPP brand drills.

\begin{tabular}{|c|c|c|c|}
\hline Depth & $1 \mathrm{~mm}^{*}$ & $5 \mathrm{~mm}^{*}$ & $P^{* *}$ \\
\hline Spear Drill & 27.1 & 31.5 & \\
\hline Drill $2.0 \mathrm{~mm}$ & 25.0 & 28.7 & \\
\hline Drill $2.8 \mathrm{~mm}$ & 24.7 & 29.5 & \\
\hline Drill $3.0 \mathrm{~mm}$ & 24.0 & 29.0 & 0.22 \\
\hline Drill $3.3 \mathrm{~mm}$ & 25.8 & 30.8 & \\
\hline Drill $3.8 \mathrm{~mm}$ & 27.5 & 31.3 & \\
\hline Drill $4.3 \mathrm{~mm}$ & 26.2 & 31.8 & \\
\hline Drill $4.8 \mathrm{~mm}$ & 27.3 & 32.1 & \\
\hline
\end{tabular}

$\mathrm{mm}=$ millimeters; values in degree Celsius $\left({ }^{\circ} \mathrm{C}\right),{ }^{*} P<0.001$; In-group Student's $t$-test, ${ }^{* *}$ Chi-square test between $1 \mathrm{~mm}$ vs. $5 \mathrm{~mm}$ depths.

Table 2: Description of block temperatures at each depth with 150 RPM without irrigation with experimental KOPP brand drills.

\begin{tabular}{cccc}
\hline Depth & 1 $\mathbf{m m}^{*}$ & $\mathbf{5 ~ \mathbf { m m } ^ { * }}$ & $\boldsymbol{P}^{* *}$ \\
\hline spear Drill & 27 & 30.9 & \\
Drill $2.0 \mathrm{~mm}$ & 25.3 & 28 & \\
Drill $2.8 \mathrm{~mm}$ & 24.1 & 29 & \\
Drill $3.0 \mathrm{~mm}$ & 23.3 & 28.3 & 0.25 \\
Drill $3.3 \mathrm{~mm}$ & 24.4 & 30.2 & \\
Drill $3.8 \mathrm{~mm}$ & 26.2 & 30 & \\
Drill $4.3 \mathrm{~mm}$ & 25.3 & 30.4 & \\
Drill $4.8 \mathrm{~mm}$ & 26.2 & 31.1 & \\
\hline
\end{tabular}

$\mathrm{mm}=$ millimeters; values in degree Celsius $\left({ }^{\circ} \mathrm{C}\right),{ }^{*} P<0.001$; intragroup Student's $t$-test, ${ }^{* *}$ chi-squared test between $1 \mathrm{~mm}$ vs. $5 \mathrm{~mm}$ depths. minimum temperature at the depth of $5 \mathrm{~mm}$ was $22.3^{\circ} \mathrm{C}$ at the spear and $26.1^{\circ} \mathrm{C}$ in the $2.8 \mathrm{~mm}$ drill. There was a statistical difference between the temperatures in the intragroup comparison of each depth $(p<0.001)$, but there was no statistical difference in the Intergroup analysis $(P=0.26)$.

Table 5 compared the different temperatures in the protocols with and without irrigation using each drill at the depth of $1 \mathrm{~mm}$. No statistical difference was observed when comparing conventional and experimental drills treated with the same protocol $(p>0.05)$. There was statistical difference $(p<0.001)$ when comparing the temperature of each drill between the groups treated without the irrigation protocol (G1 and G2) when compared to the groups treated with the irrigation protocol (G3 and G4). The last two had significant reduction in the temperature record of all drills.

Table 6 compares the different temperatures in the protocols with and without irrigation using each drill at the $5 \mathrm{~mm}$ depth. There was a statistical difference $(P<0.05)$ when comparing conventional and experimental drills treated with the same protocol. There was also statistical difference $(p<0.001)$ when comparing the temperature of each drill between the groups treated without irrigation protocol (G1 and G2) when compared to the groups treated with irrigation protocol (G3 and G4). The last two had significant reduction in the temperature record of all drills.

\section{DISCUSSION}

The success of rehabilitation with implants in clinical practice is undeniable, however failures of multifactorial origin which are often combined

Table 3: Description of the block temperatures at each depth at 150 RPM with irrigation using conventional KOPP brand drills.

\begin{tabular}{cccc}
\hline Depth & $1 \mathrm{~mm}^{*}$ & $\mathbf{5 ~ \mathrm { mm } ^ { * }}$ & $\boldsymbol{P}^{* *}$ \\
\hline Spear Drill & 18.8 & 26.2 & \\
Drill $2.0 \mathrm{~mm}$ & 18.5 & 26.2 & \\
Drill $2.8 \mathrm{~mm}$ & 21.8 & 28.9 & \\
Drill $3.0 \mathrm{~mm}$ & 21.8 & 26.9 & 0.78 \\
Drill $3.3 \mathrm{~mm}$ & 21.8 & 26.7 & \\
Drill $3.8 \mathrm{~mm}$ & 21.8 & 26.5 & \\
Drill $4.3 \mathrm{~mm}$ & 21.8 & 28.3 & \\
Drill $4.8 \mathrm{~mm}$ & 21.8 & 28.5 & \\
\hline
\end{tabular}

$\mathrm{mm}=$ millimeters; values in degree Celsius $\left({ }^{\circ} \mathrm{C}\right),{ }^{*} P<0.001$; intragroup Student's $t$-test, ${ }^{* *}$ chi-squared test between $1 \mathrm{~mm}$ vs. $5 \mathrm{~mm}$ depths.

Table 4: Description of the block temperatures at each depth at 150 RPM with irrigation and experimental KOPP brand drills.

\begin{tabular}{cccc}
\hline Depth & $\mathbf{1 ~ \mathbf { m m } ^ { * }}$ & $\mathbf{5 ~ \mathbf { m m } ^ { * }}$ & $\mathbf{P}^{* * *}$ \\
\hline Spear Drill & 18 & 22.3 & \\
Drill $2.0 \mathrm{~mm}$ & 18.3 & 24.8 & \\
Drill $2.8 \mathrm{~mm}$ & 19.5 & 26.1 & \\
Drill $3.0 \mathrm{~mm}$ & 19.5 & 25.3 & 0.26 \\
Drill $3.3 \mathrm{~mm}$ & 19.5 & 25.2 & \\
Drill $3.8 \mathrm{~mm}$ & 20.4 & 24.3 & \\
Drill $4.3 \mathrm{~mm}$ & 22.1 & 25.5 & \\
Drill $4.8 \mathrm{~mm}$ & 21 & 25.8 & \\
\hline
\end{tabular}

$\mathrm{mm}=$ millimeters; values in degree Celsius $\left({ }^{\circ} \mathrm{C}\right),{ }^{*} P<0.001$; intragroup Student's $t$-test, ${ }^{* *}$ chi-squared test between $1 \mathrm{~mm}$ vs. $5 \mathrm{~mm}$ depths. 
Table 5: Comparative analysis of the block temperatures at the depth of $1 \mathrm{~mm}$ at $150 \mathrm{RPM}$ with and without irrigation with conventional and experimental KOPP brand drills.

\begin{tabular}{|c|c|c|c|c|c|}
\hline \multirow[t]{2}{*}{ Depth } & \multicolumn{2}{|c|}{ Without irrigation** } & \multicolumn{2}{|c|}{ With irrigation ** } & \multirow[t]{2}{*}{$p^{*}$} \\
\hline & 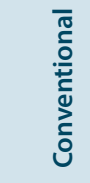 & 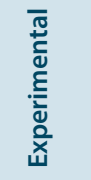 & $\begin{array}{l}\bar{N} \\
\stackrel{0}{0} \\
\stackrel{0}{\mathscr{C}} \\
0 \\
0 \\
0 \\
0\end{array}$ & 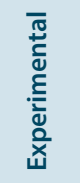 & \\
\hline Spear Drill & 27.1 & 27 & 18.8 & 18 & $p<0.001$ \\
\hline $2.0 \mathrm{~mm}$ Drill & 25.0 & 25.3 & 18.5 & 18.3 & $<0.001$ \\
\hline $2.8 \mathrm{~mm}$ Drill & 24.7 & 24.1 & 21.8 & 19.5 & $<0.001$ \\
\hline $3.0 \mathrm{~mm}$ Drill & 24.0 & 23.3 & 21.8 & 19.5 & $<0.001$ \\
\hline $3.3 \mathrm{~mm}$ Drill & 25.8 & 24.4 & 21.8 & 19.5 & $<0.001$ \\
\hline $3.8 \mathrm{~mm}$ Drill & 27.5 & 26.2 & 21.8 & 20.4 & $<0.001$ \\
\hline $4.3 \mathrm{~mm}$ Drill & 26.2 & 25.3 & 21.8 & 22.1 & $<0.001$ \\
\hline $4.8 \mathrm{~mm}$ Drill & 27.3 & 26.2 & 21.8 & 21 & $<0.001$ \\
\hline
\end{tabular}

$\mathrm{mm}=$ millimeters; values in degrees Celsius $\left({ }^{\circ} \mathrm{C}\right),{ }^{*}$ ANOVA followed by the Holm-Sidak test when comparing intergroups; ${ }^{*} P>0.05$; ANOVA followed by the Holm-Sidak test in the intragroup comparison.

can occur, thereby causing damage to the professional and the patient. Among these failures, bone overheating stands out as well as poor case planning. This elevation in temperature occurs due to the friction of the surgical drill with the bone tissue and can cause damage to osseointegration and even necrosis when it crosses the limit between $44^{\circ} \mathrm{C}$ and $47^{\circ} \mathrm{C}$ for at least one min. ${ }^{10}$

Devices with thermocouple technology can be used to check the bone temperature after drilling. ${ }^{11}$ Thermocouples are electrical devices with great application in temperature measurement. In the study by Nero et al. ${ }^{8}$ they were used to evaluate the temperatures in the medullary bone and cortical bovine during osteotomy with a $2.00 \mathrm{~mm}$ drill. External irrigation was used in the halves of the specimens, while double irrigation was used in the remaining which was more efficient in temperature control. In the present study, the groups treated with irrigation (G3 and G4) showed better temperature control when evaluating the mean values at the perforation temperatures of $1.00 \mathrm{~mm}$ depth $\left(\mathrm{G} 1: 25.95 \pm 0.46^{\circ} \mathrm{C}\right.$; G2: $\left.25.22 \pm 0.44^{\circ} \mathrm{C} ; \mathrm{G} 3: 21.01 \pm 0.52^{\circ} \mathrm{C} ; \mathrm{G} 4: 19.79 \pm 0.48^{\circ} \mathrm{C}\right)$ and $5.00 \mathrm{~mm}$ depth $\left(\mathrm{G} 1: 30.59 \pm 0.47^{\circ} \mathrm{C}\right.$; $\mathrm{G} 2: 29.74 \pm 0.41^{\circ} \mathrm{C}$; G3: $27.27 \pm 0.39^{\circ} \mathrm{C}$; G4: $\left.24.91 \pm 0.42^{\circ} \mathrm{C}\right)$. However, there were no statistical differences between the different groups.

Andriani Jr. developed a thermocouple technology device associated with a computerized system to evaluate the performance of irrigation systems (internal and external) during the preparation of the surgical bed for implant placement. The author evaluated 20 specimens of bovine bone associated with thermocouples placed at different depths and observed that the internal irrigation system generated lower heat when compared to the external irrigation system. In the present study, bovine bone was also used for presenting characteristics such as density and similar configuration to the human jaw. ${ }^{11}$

Carneiro et al. ${ }^{12}$ evaluated the influence of the cut conditions on bovine bone, monitoring the temperature through thermocouples. The authors utilized a kit of uncoated dental drills using water for irrigation. In this study, helical drills produced lower temperature values. It is known that the vascularization around the implant is one of the main responsible factors for the success of osseointegration. Maintaining this tissue during the milling process is essential. Histological studies indicate that temperatures higher than $47^{\circ} \mathrm{C}$ can inhibit bone regeneration.
Table 6: Comparative analysis of the block temperatures at the depth of $5 \mathrm{~mm}$ at 150 RPM with and without irrigation using conventional and experimental KOPP brand drills.

\begin{tabular}{|c|c|c|c|c|c|}
\hline \multirow[t]{2}{*}{ Depth } & \multicolumn{2}{|c|}{ Without irrigation } & \multicolumn{2}{|c|}{ With irrigation** } & \multirow[t]{2}{*}{$p^{*}$} \\
\hline & 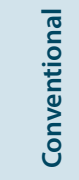 & 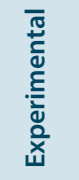 & 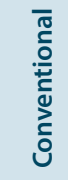 & 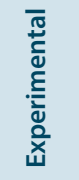 & \\
\hline Spear Drill & 31.5 & 30.9 & 26.2 & 22.3 & $<0.001$ \\
\hline $2.0 \mathrm{~mm}$ Drill & 28.7 & 28 & 26.2 & 24.8 & $<0.001$ \\
\hline $2.8 \mathrm{~mm}$ Drill & 29.5 & 29 & 28.9 & 26.1 & $<0.001$ \\
\hline $3.0 \mathrm{~mm}$ Drill & 29.0 & 28.3 & 26.9 & 25.3 & $<0.001$ \\
\hline $3.3 \mathrm{~mm}$ Drill & 30.8 & 30.2 & 26.7 & 25.2 & $<0.001$ \\
\hline $3.8 \mathrm{~mm}$ Drill & 31.3 & 30 & 26.5 & 24.3 & $<0.001$ \\
\hline $4.3 \mathrm{~mm}$ Drill & 31.8 & 30.4 & 28.3 & 25.5 & $<0.001$ \\
\hline $4.8 \mathrm{~mm}$ Drill & 32.1 & 31.1 & 28.5 & 25.8 & $<0.001$ \\
\hline
\end{tabular}

$\mathrm{mm}=$ millimeters; values in degrees Celsius $\left({ }^{\circ} \mathrm{C}\right),{ }^{\star}$ ANOVA followed by the Holm-Sidak test when comparing intergroups; ${ }^{* *} P>0.05$; ANOVA followed by the Holm-Sidak test in the intragroup comparison.

Faria $^{13}$ evaluated the temperature generated during the preparation of the bovine bone tissue by comparing the Nobel and $3 \mathrm{i}$ connection systems. After perforations with drills of $2.0 \mathrm{~mm}$ and $3.0 \mathrm{~mm}$ diameter up to $13 \mathrm{~mm}$ depth, at a speed of $1500 \mathrm{rpm}$ with intermittent pressure of $2 \mathrm{~kg}$ under constant irrigation at room temperature $\left(24 \pm 1^{\circ} \mathrm{C}\right)$, it was observed that the $2 \mathrm{~mm}$ diameter connection system had better results in relation to minimizing the temperature increase; however, none of the drills exceeded the biological limit. Factors such as motor rotation speed, drill design and pressure should be controlled. In the intragroup analysis of each studied protocol herein, there was a statistical difference between the temperatures of the different drills at each depth $(p<0.001)$. However, there was no statistical difference in comparing the values of the different depths studied in the Intergroup analysis.

Geerts and Patel ${ }^{6}$ evaluated the temperature changes along the surface of the implant in vitro through thermocouples at ten min intervals and established that the temperature threshold that the abutment could reach is $47^{\circ} \mathrm{C} / 1 \mathrm{~min}$. In a total of 53 series of tests, the temperature of the abutment varied between $52.80^{\circ} \mathrm{C}$ and $71.72^{\circ} \mathrm{C}$, having an association between the maximum temperature, the implant level and the temperature of the abutment. The threshold of $47^{\circ} \mathrm{C} / 1 \mathrm{~min}$ was reached 31 times at the implant level and the temperature was lower in areas farther away from the heat source. For an abutment temperature of $62.3^{\circ} \mathrm{C}$ there was a $50 \%$ chance that $47^{\circ} \mathrm{C}$ would be reached for $1 \mathrm{~min}$ at the implant level.

Gehrke et al. ${ }^{14}$ evaluated whether there were differences in temperature variation using only a single drill for the preparation of surgical drill and compared with the conventional drill sequence using various drills in bovine bone. Three groups were evaluated: one group using three consecutive $4.1 \mathrm{~mm}$ cylindrical drills, one using three consecutive drills for a $4.3 \mathrm{~mm}$ conical implant and a third group with only one drill for a $4.2 \mathrm{~mm}$ conical implant. The temperature in the cortical bone was measured through a thermocouple. The same experiment with external irrigation was repeated without irrigation, in which the protocol with only one drill showed no greater bone heating than the conventional one. When comparing temperature values when using each drill in the different protocols in the present study, the treated groups without irrigation had a significantly higher temperature than those with irrigation protocol $(p<0.001)$. 
Soldatos et al. ${ }^{15}$ measured the temperature in the surgery of different implant designs, including a conical, a self-tapping conical and a parallel wall design. The drills were compared with and without external irrigation at rotations of 800,1000 and $1200 \mathrm{rpm}$. The highest temperature was found with the initial drills for conical implants and the lowest for the initial drills for self-tapping conical implants. Irrigation especially influenced the self-tapping design. The authors concluded that different implant designs have different thermodynamic behaviors.

Strbac et al. ${ }^{16}$ evaluated changes in temperature during osteotomy in bone samples. For this purpose, 160 automatic intermittent osteotomies (10/16 mm deep drilling) were performed with $2 \mathrm{~mm}$ helical drills and $3.5 \mathrm{~mm}$ conical drills with and without irrigation. In their study, it was observed that the greatest changes in temperature were during the drill removal with the influence of irrigation. According to the authors, the progressive increase in temperature may modify the mineral structure of the bone hydroxyapatite.

Several studies have shown that atraumatic surgical techniques that prevent the implant site overheating and primary stability are the two main factors involved in the success of osseointegration. ${ }^{17}$ Bone perforation is a highly contested topic due to the heat production caused by this procedure. Several factors interfere with bone drilling and it is essential to develop new technologies in order to control them. ${ }^{18}$

\section{CONCLUSION}

In the present study it can be concluded that the groups of bovine blocks treated with irrigation had lower temperature records when compared to the groups without irrigation protocol for both studied depths.

\section{ACKNOWLEDGEMENT}

We acknowledge all participants and São Leopoldo Mandic College.

\section{CONFLICT OF INTEREST}

The authors declare that there is no conflict of interest.

\section{ABBREVIATIONS}

Mm: Millimeter; RPM: Revolution per minute.

\section{REFERENCES}

1. Galindo DF, Butura CC. Immediately Loaded Mandibular Fixed Implant Prostheses using the All-On-Four Protocol: A Report of 183 Consecutively Treated
Patients with 1 Year of Function in Definitive Prosthes. International Journal of Oral and Maxillofacial Implants. 2012;27(3):628-33.

2. Lioubavina-Hack N, Lang NP, Karring T. Significance of primary stability for osseointegration of dental implants. Clin Oral Implants Res. 2006;17(3):244-50.

3. Faverani LP, Ferreira GR, Jardim ECG, Okamoto R, Shinohara EH, AssunçãoWG, et al. Implantes osseointegrados: Evolução sucesso. Salusvita. 2011;30(1):47-58.

4. Babbush C, Kanwati A, Brokloff J. A New Approach to the All-on-Four Treatment Concept Using Narrow Platform Nobel Active Implants. J Oral Implantol. 2013;39(3):314-25.

5. Bulutsuz AG, Tanyel RC, Katiboglu AB. Measurement of temperature change during the implant site preparation to determine influence of tool characteristics. Measurement. 2016;79:354-9.

6. Geerts GAVM, Patel Z. Temperature changes along a dental implant. Int J Prosthodont. 2011;24(1):58-68.

7. Lucas RRS, Gonçalves R, Pinheiro MPF, Pinheiro AR, Alto RVM. Fatores que afetam a osseointegração dos implantes-Uma Revisão. Rev Flum Odontol. 2013;19(39):3-10.

8. Nero ALD, Gehrke SA, Bortolo JN, Zanatta LC. Temperatura durante a fresagem óssea. Estudo comparativo das técnicas de irrigação. Rev Assoc Paul Cir Dent. 2012;66(2):147-50.

9. Instituto Nacional de Propriedade Industrial. Depósito de pedido nacional de patente. 2017. BR2020170107359.

10. Alves LMN, Hidalgo LRC, Conceição LS, Oliveira GM, Borges KRF, Passos WG Implants complications: A literature review. J Orofac Invest. 2017;4(1):20-9.

11. Andriani JW. Mensuração do calor friccional gerado pelo preparo do tecido ósseo em implantodontia: estudo in vitro. Dissertação de Mestrado, Programa de Pós-Graduação em Odontologia da Universidade Federal de Santa Catarina: Florianópolis. 2002.

12. Carneiro MB, Medeiros RLR, Machado ÁR, Gomes VL, Soares MAD, Luiz NE. Influência das condições de corte no preparo de lojas receptoras de implantes dentais. Desenvolver habilidades e competências é imprescindível para sua carreira. Innov Implant J Biomater Esthet. 2009;4(1):13-8.

13. Faria R. Avaliação da temperatura gerada e do tempo gasto durante o preparo do tecido ósseo com a utilização de brocas de diferentes sistemas de implantes. Dissertação de Mestrado, Programa de Pós-Graduação em Odontologia Restauradora da Universidade Estadual Paulista. São José dos Campos. 2005.

14. Gehrke SA, Bettach R, Taschieri S, Boukhris G, Corbella S, DelFabbro M. Temperature Changes in Cortical Bone after Implant Site Preparation Using a Single Bur versus Multiple Drilling Steps: An in vitro Investigation. Clin Implant Dent R. 2015;17(4):700-7.

15. Soldatos N, Gozalo D, Moreno D, Powell C. Temperature Changes During Implant Osteotomies Utlilizing Three Different Implant Systems: A Pilot Study. JIACD. 2016;8(7):34-43.

16. Strbac GD, Giannis K, Unger E, Mittlböck M, Vasak C, Watzek G, et al. Drillingand withdrawing-related thermal changes during implant site osteotomies. Clin Implant Dent R. 2015;17(1):32-43.

17. Trisi P, Berardini M, Falco A, Vulpiani MP. Effect of temperature on the dental implant osseointegration development in low-density bone: An in vivo histological evaluation. Implant Dent. 2015;24(1):96-100.

18. Fernandes MGA, Fonseca EMM, Natal R. Modelo 3D para análise térmica durante o processo de furação do osso cortical. Rev Ass Port Anál Exp de Tens. 2015;(25):11-9.

Article History: Submission Date : 22-01-2019; Revised Date : 17-02-2019; Acceptance Date : 13-04-2019.

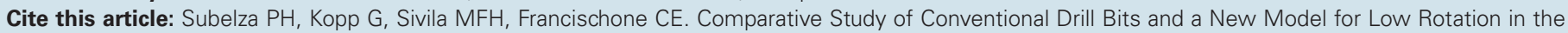
Surgical Bed Preparation in Bone Blocks for Installation of Dental Implants. J Young Pharm. 2019;11(4):429-33. 